UDC:330.339.334.7

https://doi.org/10.33619/2414-2948/39/28

JEL classification: O38 Q18; R51

\title{
CURRENT STATE OF THE DEVELOPMENT OF SMALL BUSINESS AND PRIVATE ENTREPRENEURSHIP AND ITS ORGANIZATIONAL-ECONOMIC MECHANISMS IN THE FIELD OF SERVICE IN UZBEKISTAN
}

CMasharipova M., Urgench State University, Urgench, Uzbekistan, manzuramohira@mail.ru

\section{СОВРЕМЕННОЕ СОСТОЯНИЕ РАЗВИТИЯ МАЛОГО БИЗНЕСА И ЧАСТНОГО ПРЕДПРИНИМАТЕЛЬСТВА И ЕГО ОРГАНИЗАЦИОННО-ЭКОНОМИЧЕСКИХ МЕХАНИЗМОВ В СФЕРЕ УСЛУГ В УЗБЕКИСТАНЕ}

\author{
(Смашарипова М. А., Ургенчский государственный университет, \\ г. Ургенч, Узбекистан, manzuramohira@mail.ru
}

Abstract. This article presents current issues of gradual, systematic and continuous improvement of organizational and economic mechanisms of development of small business and private entrepreneurship in service sphere of Uzbekistan as well as ensuring a unified integrated approach to solve problems in support of this sphere. It is assumed that the implementation of the above reforms will lead to further improvement of the organizational and economic mechanisms for the development of small business and private entrepreneurship not only in the field of service but also in economic sectors. In addition, the article contains the following legislative acts, their content and essence, and scientific recommendations.

Аннотация. В статье представлены актуальные вопросы как постепенное, системное и постоянное совершенствование организационно-экономических механизмов развития малого бизнеса и частного предпринимательства в сфере услуг в Узбекистане, а также обеспечение единого комплексного подхода к решению проблем поддержки данной сферы. Предполагается, что реализация вышеуказанных реформ приведет к дальнейшему совершенствованию организационных и экономических механизмов развития малого бизнеса и частного предпринимательства не только в сфере услуг, а также в секторах экономики. Кроме того, в статье представлены законодательные и нормативные документы по развитию отрасли, их содержание и сущность и научные рекомендации.

Keywords: entrepreneurship, business, small business, private enterprise, mechanism, organizational and economic mechanism, economic mechanism, service.

Ключевые слова: предпринимательство, бизнес, малый бизнес, частное предпринимательство, механизм, организационно-экономический механизм, экономический механизм, сервис, сервисное обслуживание.

Small business and private entrepreneurship (SBPE) have become a very important sector in the socio-economic development of the Republic of Uzbekistan. Indeed, the share of SBPE in GDP was $1,8 \%$ in 1991 and it increased up to $31,0 \%$ in 2000 . As a result of the attention being paid to the 
sphere, the systemic and comprehensive support and incentives provided by the government for many years, the share of SBPE in GDP of the country made up 53.3\% by the end of 2017.

Also, the role of small businesses in the labor market in Uzbekistan as an employer is one of its most important social functions. According to statistics and leading media, 2/3 of the total number of jobs per year is created in the sphere of small entrepreneurship. The role of small business plays an important role both in times of crisis and in depressive areas. Thus, small businesses can help millions of people overcome difficulties and thus contribute to the social tension in society.

According to Doing Business — 2018, presented by World Bank in October 2018, Uzbekistan ranks 13th in the World Bank's "Business Clothes-2018" ranking and is among the top ten countries in the world in improving the business environment [1].

In addition, the role of the service sector in Uzbekistan is characterized by its uniqueness. At the same time, the share of service sphere in the GDP of Uzbekistan was more than $47.3 \%$ in 2017, while it was showing low share in the GRP of many regions (for example, $46.9 \%$ in Khorezm region in 2016) constitutes an organizational and economic mechanism to improve the quality of their services.

Our research on sustainable development and regulation of SBPE in the regions and sectors of the economy suggests that in particular country or region, the region's specific socio-economic development, geodemographic, socio-cultural, natural-climatic and other factors, specific organizational and economic mechanisms should be used. In particular, new business start-ups and entrepreneurs need entrepreneurship training, business planning support, preferential microloans, business consulting, building and renting benefits, while developing countries have pledged to secure a portion of the interest rate leasing, equipment leasing, medium-term loans, and borrowing.

For those who are strongly established in the market, priority is given to access to state and local orders, assistance in accessing foreign markets, facilitating participation in various international and national exhibitions, contests, and involvement of national and foreign investment.

In our view, the inadequacy of the methods and forms of government regulation in the context of each stage of the development of the SBPE activity reduces the effectiveness of regulation. This is why the transition to world-renowned market relations in Uzbekistan during the years of independence, developed by I. Karimov, and improving the organizational and economic mechanisms of the SBPE in accordance with the well-known five principles of the model named "Uzbek model" in the world community, were carried out in an evolutionary way together with the pace of common market reforms.

The development and regulation of SBPE are through the development of special government programs in most developed countries. These programs may include various measures based on the goals and objectives of the regulation, the opportunity and the circumstances.

Economist scientist U. V. Gafurov in his doctoral dissertation provided the provision of preferential loans and subsidies as the most widely used types of state regulation of SBPE development, the introduction of simplified taxation, setting tax breaks, promoting new product creation and introduction, providing guaranteed sales markets for products, training and retraining of personnel [4].

The subjects of SBPE is a combination of business entities, that is small businesses, micro firms and individual entrepreneurs, operating within the framework of the current law, whose main aim is to obtain entrepreneurial income (profit).

This classification has changed step-by-step on a number of normative-legal acts between 1992 and 2017, and as of 2017, the subjects of SBPE employed in the individual entrepreneur includes 200 workers in industry-intensive sectors (www.lex.uz). 
Likewise, the subjects of SBPE may be apparently merely as commercial organizations, as well as professional and social associations of enterprises, and they are united to gain benefit from the discretionary account .Because, in today's globalization and the sharp competition, we need not only economic, but also social, environmental, and political-cultural activities.

Leo Gurvits, who won the Nobel Prize for his significant contribution to the Mechanism Design Theory in 2007, the Roger Mayerson was awarded for his study of the problems of optimal auctions and Eric Maskin was awarded for the concept of universal implementation of the economic mechanism [1]. In the modern theory of economic institutions, the results of the above studies are mainly derived.

Also in the theory of economic mechanisms, Russian scientists V. Slepov, V. K. Burlachkov and K.V. The Orloves are studying information and functional approaches to problem-solving [2].

Another economist scientist A. Yu. Chalenko underscores the following distinctive features of the economic mechanism [5]:

- There is no mechanism that can not be processed, i.e. the mechanism is created only to fulfil the tasks of the process;

- The mechanism does not have control, as if it were "inactive" and that process was in control;

- Integrating mechanism with management is the internal content of the process.

Moreover, A. Yu. Chalenko describes the economic mechanism as the sum of the resources of the economic process and the methods of their integration, as well as the social, economic, ecological and technological resources that belong to the territorial unit of SBPE business. Because the development of SBPE entities is directly related to the development of a territorial unit (region, region, city, district), which is the organizational-economic mechanism of SBPE development .

In the scientific literature, the concept of "mechanism" is used in different meanings: the concepts of "regulatory mechanism", "state participation mechanism", "control mechanism".

Also, organizational and economic mechanism of the development of SBPE is based on 3 main concepts: "mechanism", "development" and "SBPE". According to him, the development of SBPE is a multi-faceted process, in which the relationship between the industry and the environment, at the local, regional and national levels, is the "internal environment", which means relations among them.

The economic mechanism is a system, which defines the order of the type of activity. In addition, economic mechanism is a sum of the forms of social production include the division of labor, the specialization and placement of production, the organizational structures applied in the implementation of economic laws and re-production processes, forms and forms of economic, legal, socio-psychological management, forms, processes, a combination of economic benefits and incentives affecting the activities of undertakings.

The SBPE economic mechanism is both multidisciplinary and theoretically multidimensional, and contributes to the harmony of not only SBPE, but also the social and private interests of the national economy.

The economic mechanism, as representing the implementation of economic laws, includes organizational and economic mechanisms of several government policies, including finance, investment, credit, financial, material resources, insurance, reinsurance, compensation, economic incentives and accountability [3].

Comparative analysis, logical analysis, structural analysis, statistical grouping, synthesis, induction and deduction methods were used in the research.

According to our analysis, primarily, government should create favourable conditions in order to develop SBPE, for example, (prevention corruption, bureaucratic control, tax system 
optimization, protection against harassment, etc) and provide with direct support (legal, economic, financial support, and preferences, etc.).

In countries those are the transition from the administrative-command system to the market economy, the main objective of SBPE support is to increase the number of subjects of the sphere, the share of the field in GDP, the share of the employed in the economy, and tax revenues.

However, it should be noted that, according to prof S.Salayev, it is nearly impossible to increase uninterruptedly the share of SBPE in macroeconomic indicators in any country or region or, in other words, it can grow up to $100 \%$ theoretically in the region, depending on its specific features, in a particular industry or sphere [3].

It should be noted that as a result of measures taken to support and further stimulate small business and private entrepreneurship in the Republic of Uzbekistan in January-December 2017, more than $38.2 \%$ small businesses (without farms) were opened or, as compared to the same period of 2016 Increased by $122.0 \%$.

The steady growth of SBPE in Uzbekistan, which plays an important role in the economy, is the state's comprehensive support. Also, we can see from table 1 below that the share of SBPE in the national economy achieved a steady increase between 2005 and 2017.

In particular, the share of the industry in the Republic of Uzbekistan increased from $10 \%$ in 2005 to $40.6 \%$ in $2017,98.6 \%$ in agriculture, $66.7 \%$ in construction and $50.5 \%$ in service sector.

Table

THE SHARE OF SMALL BUSINESS AND PRIVATE ENTREPRENEURSHIP IN 2005-2017 IN THE ECONOMIC SECTORS OF THE REPUBLIC OF UZBEKISTAN, (\%) [18]

\begin{tabular}{lccccccc}
\hline & mean & 2007 & 2009 & 2011 & 2013 & 2015 & 2017 \\
\hline Industry & 10,0 & 13,2 & 17,9 & 21,9 & 28,1 & 40,6 & 41,2 \\
Construction & 50,9 & 55,4 & 42,4 & 68,6 & 71,5 & 66,7 & 64,8 \\
Trading & 88,2 & 87,8 & 81,0 & 86,7 & 86,6 & 87,1 & 88,4 \\
Service & 52,5 & 50,1 & 46,9 & 46,3 & 46,2 & 50,5 & 58,4 \\
Export & 6,0 & 14,8 & 14,6 & 18,8 & 26,2 & 27,8 & 27,2 \\
Import & 33,7 & 32,0 & 42,5 & 34,3 & 42,4 & 44,5 & 50,2 \\
\hline
\end{tabular}

In our view, it is desirable to classify organizational and economic mechanisms for the development of SBPE directly depending on which object:

national development mechanisms of SBPE;

mechanisms for the development of SBPE in a particular sector of the economy;

regional or regional development mechanisms for SBPE;

mechanisms for the external or internal development of the SBPE;

mechanisms for the development of a particular SBPE subject, which are of strategic important;

mechanisms for improving the economic phenomena and processes directly related to SBPE, etc.

Secondly, the organizational and economic mechanisms of SBPE development in the service sector may be aimed at improving the development of insufficiently developed services and services that have not previously been developed, that is to say, the development of new types of service or the introduction of existing service types in a sustainable. Based on our analysis of the research, there are the following organizational and economic mechanisms for government to support SBPE in general: 
1. Normative and legal mechanism for the regulation of Small business and private entrepreneurship. This mechanism basically covers the various legislative acts of the Republic of Uzbekistan that are directly and indirectly regulated by the SBPE activity, Decrees, Resolutions of the President of the Republic of Uzbekistan, Resolutions of the Cabinet of Ministers of the Republic of Uzbekistan, other laws adopted by the ministries and committees and agencies.In particular, the main normative and legal acts are the laws of the Republic of Uzbekistan "On Entrepreneurship in the Republic of Uzbekistan" № 207-XII of 15 February 1991 and "On Denationalization and Privatization of the Republic of Uzbekistan" of 19 November 1991, 425-XII, more than 500 different legal acts have been adopted so far.Based on these legislative acts, the Decree of the President of the Republic of Uzbekistan dated March 18, 2017 №-2897 "On Establishment of the State Committee of the Republic of Uzbekistan for the Promotion of Privatized Enterprises and Development of Competition", №-2895, dated March 18, 2017, "Measures about improving efficiency of working with privatized enterprises" and Resolution of the Cabinet of Ministers of the Republic of Uzbekistan "On measures to streamline the system of microcrediting of business entities and the broad public" dated March 17, 2017, and Decree of the President of the Republic of Uzbekistan "On Establishment of the Institute for the Protection of the Rights and Legal Interests of Entrepreneurs" №-5037 dated May 5, 2017 became an important page in the further development of the activities of SBPE subjects. Because, according to the aforementioned Decree №-2897, comprehensive support for the recovery and improvement of productivity of privatized enterprises, creation of new workplaces to ensure sustainable growth of the income of the population, on the basis of the aim to adapt strong cooperation of activity among the competent state bodies, financial and other market structures, Coordination of the joint activities of the Chamber of Commerce and local authorities are one of the most important task of the newly established Committee of the Republic of Uzbekistan for the Promotion of Privatized Enterprises and Development of Competition.

Also, according to the Decree of the President of the Republic of Uzbekistan №-5037, the Institute for the Representative of the Republic of Uzbekistan for Protection of Rights and Legal Interests of Entrepreneurs (Entrepreneur Ombudsman) was established. The representative is responsible for the participation in the formation and implementation of public policy in this area, the rights and legitimate interests of entrepreneurs as well as oversight over the implementation of legal acts, as well as legal support of business entities. Also, it makes proposals related to the current legislation and requirements of the legislation, evaluating the impact of their activities on entrepreneurial activity, improving the legislation on strengthening legal guarantees and stimulating development of entrepreneurship.

2. Financial Support Mechanisms of Small business and private entrepreneurship. This mechanism includes all the documentation and lever that are directly related to the financing, crediting and rendering of micro leasing services to SMB entities. As a result of measures undertaken by the government to support SMEs in recent years, the volume of loans provided by commercial banks and the volume of microfinance services are growing from year to year. Particularly, Resolutions of the President of the Republic of Uzbekistan PR-2746, dated January 31, 2017, and PR-2844, dated 17 March 2017 highlight issues related to allocating credits to the activity without establishment of a new registered legal entity in distant and difficult areas, loans to individual entrepreneurs and family entrepreneurs in the amount of up to 100 times the minimum wage at the expense of the special lending program and also the main objectives of preferential microcrediting are to provide maximum access to microfinance services to SMEs, first of all, to create new jobs in family and private entrepreneurship, to provide them with concessional loans for active participation in entrepreneurship activities, and increasing the income of low-income and 
disadvantaged population, increasing the role of self-governing bodies in the employment of the population [12].

At the same time, the size of the microcredit with preferential microcredits is up to 200 times the size of the minimum wage, up to three years with the term of grace period of six months, with the following percentages per annum: 1 job creation $-9 \%, 2$ workplaces $-8 \%, 3-4$ jobs $-7 \%$, $5 \%$ and more jobs $-6 \%$.

3.Mechanisms of property support for SBPE. According to this mechanism, the CEDAW is provided by state authorities and local self-governing bodies in the form of property support, as well as delivery or use of state or private ownership, as well as land parcels, construction,nonresidential buildings, equipment, machinery, mechanisms, devices, vehicles, and inventory, particularly, the "zero value" of business premises is an example.

4. Infrastructure support mechanisms for SBPE are primarily designed to support all types of infrastructure, incentives. The State Committee of the Republic of Uzbekistan on Statistics, the Ministry of Economy, the State Committee for the Promotion of Privatized Enterprises and Competition, Chamber of Commerce and Industry, commercial banks, rating agencies, investment funds and exchanges, auditors, depositaries, insurance companies, export-import companies, information and consulting companies, which is meant to provide assistance provided by newly remodeled "single window" organizations. Particularly, the development of SBPE, implementation of various programs, placement of orders for goods and services for government needs, formalizing credit documentation, registration, licensing, certification and so on.

Nevertheless, existence of some institutional problems, for instance, weak property base of small business (deficit of fixed assets), deficiencies in fulfilment of obligations under credit agreement, business profitability and problems with getting a loan due to a high degree of credit risk, high requirements of banks to provide collateral, a huge cost to entrepreneurs to find their place into the market, as well as the high rent for non-residential buildings,lack of skilled staff, problems associated with the price change and export of goods and services in the regional and international markets, lack of adequate response from local self-governance bodies to SBPEquestions.

It should be noted that from June 1, 2017, together with the relevant ministries, committees and Council of Ministers of the Republic of Karakalpakstan, government of regions and the city of Tashkent, will organize training courses in the premises of professional colleges for entrepreneurs implementing projects on the basis of privatized objects in each district, within three months, entrepreneurs who are starting a new business will have a business-related issue related to preparing business plans, obtaining necessary information and conducting business operations, and also establishment of business incubators to give proposals for solving business-related issue with legal advice and assistance of experts.

In conclusion, the gradual, systematic and continuous improvement of organizational and economic mechanisms for the development of CMEs can be achieved by the followings:

- providing a single comprehensive approach to the development and support of SBPE in the regions of the Republic;

- applying the single principle of governance in all areas of SBPEdevelopment, stages of designing and implementing them;

- provision of targeted, efficient use of funds aimed at developing and supporting regional SBPE;

- ensuring coordination of activities of infrastructure organizations for support of SBPE;

- improving the quality and reliability of administrative solutions based on the creation and use of unique scientific-methodological support; 
- providing targeted control over the implementation of programs.

We believe that implementing the aforementioned reforms will lead to further improvement of organizational and economic mechanisms of SBPE development in the country not only in the service sector, but also in all sectors of the economy.

\section{References:}

1. Izmalkov, K. I. Sonin, M. M.., \& Yudkevich, M. (2008). Theory of economic mechanisms (Nobel prize in Economics 2007). Problems of Economics, (1). 4-26.

2. Shishkin, D. G., \& Gershanok, G. A. (2012). Importance and classification of business organizations. Journal of Russian entrepreneurship, (22). 63-69.

3. Eshchanov, B., Grinwis, M., \& Salaev, S. (2012). Price and income elasticity of residential electricity consumption in Khorezm. In Cotton, Water, Salts and Soums: Economic and Ecological Restructuring in Khorezm, Uzbekistan, 155-167.

4. Gafurov, U. V. (2016). Improving economic mechanisms of state regulation of small business. Tashkent, 53.

5. Chalenko, A. Yu. (2010). The conceptual uncertainty of the term "mechanism" in economic research. Industrial economics, (3 (51)). 26-33.

\section{Список литературы:}

1. Измалков С., Сонин К., Юдкевич М. Теория экономических механизмов (Нобелевская премия по экономике 2007 г.) // Вопросы экономики. 2008. №. 1. С. 4-26.

2. Шишкин Д. Г., Гершанок Г. А. Значение и классификация субъектов предпринимательства // Российское предпринимательство. 2012. № 22. С. 63-69.

3. Eshchanov B., Grinwis M., Salaev S. Price and income elasticity of residential electricity consumption in Khorezm // Cotton, Water, Salts and Soums: Economic and Ecological Restructuring in Khorezm, Uzbekistan. 2012. P. 155-167.

4. Гафуров У. В. Совершенствование экономических механизмов государственного регулирования малого предпринимательства. Ташкент. 2016. 53 с.

5. Чаленко А. Ю. О понятийной неопределенности термина «механизм» в экономических исследованиях // Экономика промышленности. 2010. №. 3 (51). С. 26-33.

Работа поступила

в редакцию 20.01.2019 г.
Принята к публикациии 25.01.20192.

Cite as (APA):

Masharipova, M. (2019). Current state of the development of small business and private entrepreneurship and its organizational-economic mechanisms in the field of service in Uzbekistan. Bulletin of Science and Practice, 5(2), 215-221. https://doi.org/10.33619/2414-2948/39/28 (in Russian).

Ссылка для цчитирования:

Masharipova M. Current state of the development of small business and private entrepreneurship and its organizational-economic mechanisms in the field of service in Uzbekistan // Бюллетень науки и практики. 2019. Т. 5. №2. С. 215-221. https://doi.org/10.33619/24142948/39/28. 